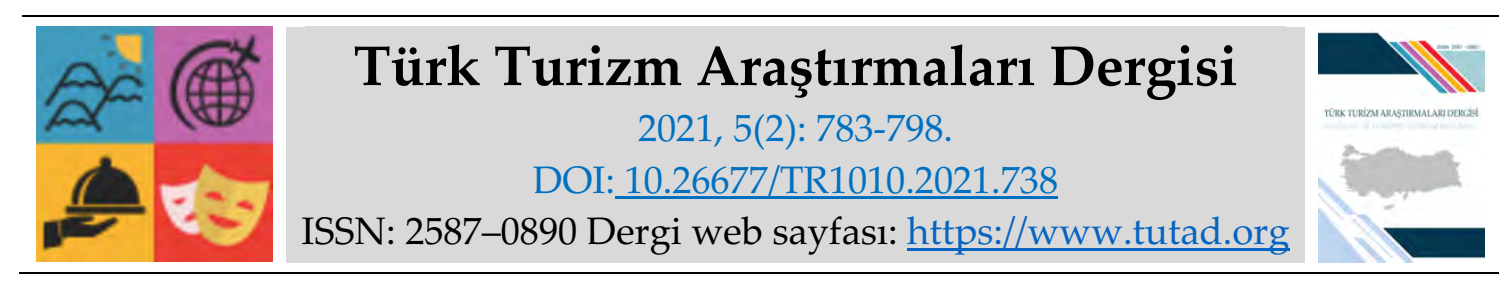

ARASTIRMA MAKALESI

\title{
Turistik Doğu Ekspres Tren Yolculuğunun Değerlendirilmesi
}

Dr. Öğr. Üyesi Gülşen BAYAT, Iğdır Üniversitesi, Turizm Fakültesi, Iğdır, e-posta: gulsen.bayat@igdir.edu.tr

ORCID: https://orcid.org/0000-0001-9955-3075

Öz

Bu çalışmanın amacı, turistik amaçlı tren seyahatine katılan kişilerin seyahat deneyimlerini ve bu seyahati daha hoş ve talep gören bir deneyim haline getirebilmek için Doğu Ekspres turistik tren seyahati boyunca sunulan hizmetlerin kalitesini değerlendirmektir. Nitel araştırma yöntemi kullanılan araştırmada, görüşmeler 25-28 Ocak 2019 yılında yapılmıştır. Turistik Doğu Ekspres ile Ankara- Kars seferine katılan, Kars'a iniş yapan ve görüşmeyi kabul eden 56 yolcu ile 25-35 dakika arası kalıcı görüşmeler gerçekleştirilmiştir. Görüşmeler neticesinde elde edilen bulgulara göre, katılımcıların hepsi bu yolculuğu başkalarına tavsiye etmektedir. Bu seyahati tercih etme nedenlerinden en çok tekrar edilenler doğal güzellik, turistik gezi, reklam, nostalji ve ucuzluktur. Hizmetlerdeki yetersizliklerden en çok tekrar edilen tuvalet temizliği ve lavaboların dar olması, vagonlardaki elektrik prizlerindeki yetersizlik, duraklarda durma sürelerinin az olması ve havalandırma ve ışıklandırma sistemlerindeki eksiklikler şeklindedir. Kars'ta yapılabilecek aktiviteler ise Sarıkamış Kayak merkezine gitmek, yöresel yemekleri tatma ve Çıldır Gölünde kıză̆a binmek şeklindedir.

Anahtar Kelimeler: Demiryolu Turizmi, Doğu Ekspres Treni, Nostaljik Trenler, Tren Yolculuğu. Makale Gönderme Tarihi: 15.12 .2020

Makale Kabul Tarihi: 01.06.2021

\section{Önerilen Atıf:}

Bayat, G. (2021). Turistik Doğu Ekspres Tren Yolculuğunun Değerlendirilmesi, Türk Turizm Araştırmaları Dergisi, 5(2): 783-798.

(c) 2021 Türk Turizm Araştırmaları Dergisi. 


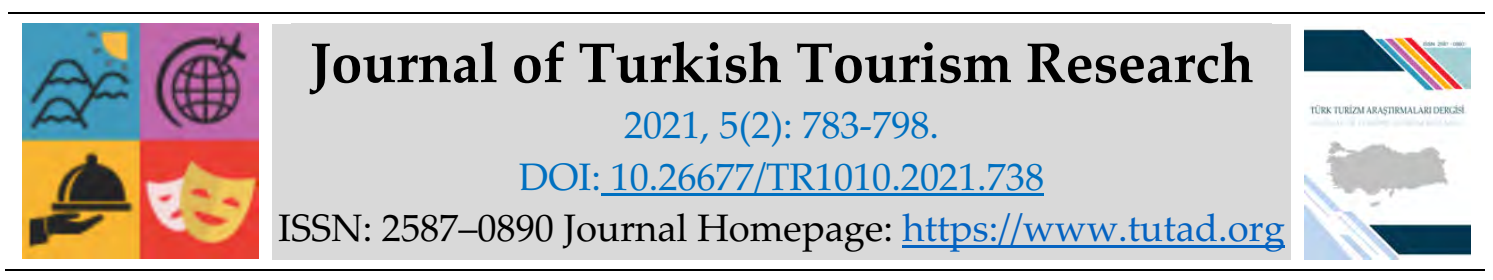

\title{
RESEARCH PAPER
}

\section{Evaluation of Touristic East Express Train Travel}

Assistant Prof. Dr. Gülşen BAYAT, Iğdır University, Faculty of Tourism, Iğdır, e-mail: gulsen.bayat@igdir.edu.tr ORCID: https://orcid.org/0000-0001-9955-3075

\begin{abstract}
The aim of this study is evaluating the travel experiences of a group of people participating in touristic train travel. In addition, it is evaluating the quality of the services offered during the Eastern Express tourist train journey in order to make this travel a more pleasant and demanding experience. In the research, in which qualitative research method was used, interviews were conducted on 25-28 January 2019. With 56 passengers participating in the Ankara-Kars expedition, landing in Kars and accepting the meeting with the Touristic East Express, permanent meetings of 25-35 minutes were made. According to the findings obtained as a result of the interviews, all of the Participants recommend this journey to others. The most frequently repeated reasons for choosing this travel are natural beauty, touristic trips, advertising, nostalgia and cheapness. The most frequent insufficiencies in services include toilet cleaning and narrow washbasins, insufficiency of electrical outlets in wagons, shorter stopping times at stops, and deficiencies in ventilation and lighting systems. Activities to participate in Kars include going to Sarıkamış Ski Center, tasting local dishes and riding a sled in Çıldır Lake.
\end{abstract}

Keywords: Railway Tourism, East Express Train, Nostalgic Trains, Train Travel.

Received: 15.12 .2020

Accepted: 01.06.2021

\section{Suggested Citation:}

Bayat, G. (2021). Evaluation of Touristic East Express Train Travel, Journal of Turkish Tourism Research, 5(2): 783-798.

(C) 2021 Türk Turizm Araştırmaları Dergisi. 


\section{Gíriş}

Turizm insanların alışık oldukları çevrelerin dışına tatil, iş ve çeşitli amaçlarla yaptıkları geçici seyahatler ve konaklamalardır (Holloway ve Taylor, 2006). Sosyal ve ekonomik yaşam üzerinde önemli etkisi olan turizm, dünyanın önde gelen sektörleri arasında yer alır. Altyapı gelişimi ile beraber yarattığ ${ }_{1}$ iş fırsatları sayesinde bu sektörden elde edilen gelir, toplumun pek çok kesimini etkilemektedir (https://wttc.org/).

Turizm, gelişmiş ve gelişmekte olan ülkelerin ve az gelişmiş kırsal bölgelerin kalkınması için çok önemli bir sektördür. Kırsal bölgelere özgü turizm türleri ile kırsal bölgelerin ekonomileri canlılık kazanabilir. Çünkü günümüzde boş zaman ve gelir artışına bağlı seyahatler her geçen gün artmaktadır. Turistler farklı seyahat deneyimi yaşama arayışı ile farklı turizm türlerine yönelmektedirler. Bu turizm türlerinden biri de tüm duyularımıza hitap eden (Larsen, 2011) tren ile yapılan turistik seyahatlerdir. Tren ile yapılan seyahatler insanlara farklı seyahat deneyimi yaşama fırsatı yarattığı için dünyanın pek çok noktasında önemli bir seyahat alternatifidir. Ayrıca önemli bir deneyim ve kültürel miras kaynağıdır (Henderson, 2011).

Doğu Ekspres turistik tren seyahati boyunca sunulan hizmetlerin kalitesini ve bu seyahati daha hoş ve talep gören bir deneyim haline getirebilmek için, demiryolu turizmi ve dünyadaki önemli demiryolu rotaları ile ilgili kuramsal inceleme yapılmıştır. İkinci olarak Doğu Ekspres tren seyahatine katılan yolcuların demografik ve seyahat bulguları ile beraber tren seyahati boyunca sunulan hizmetin kalitesi ile ilgili araştırma sorularının cevaplarına yönelik araştırma bulgularına yer verilmiştir.

\section{DEMIRYYLU TURİMI}

Ulaşım, turistlerin yaşadıkları yerlerdeki kökenleri ile gidecek yer arasındaki bağlantıyı sağlayan, seyahat deneyiminin en önemli parçasıdır (Su ve Wall, 2009:651). Bu seyahatin demiryolunu kullanarak, turizm ve eğlence amaçlı yapılmasına demiryolu turizmi denir (Jessen, 1999). Turistlerin ulaşım aracı olarak treni kullanarak gerçekleştirdiği turizm ve diğer boş zaman seyahatleri demiryolu turizmi olarak adlandırılır.

Başlangıçta trenler kısa mesafeli turist ihtiyaçları için özel olarak tasarlanmış ve inşa edilmiş, ancak zamanla İsviçre gibi ülkelerde geniş bir yelpazede kullanılmaya başlanmıştır. Fransa ve İtalya gibi ülkelerde özel girişimler sayesinde, özellikle tatillerde ve belirli etkinliklerde kullanılmak için küçük hatlar boyunca tarihi eski trenler (şarap treni, dağ treni, denize giden tren) gibi farklı alternatiflerle özel hizmetler sunulmuştur (Gattuso vd., 2019:2011-2013). Fransa'da yaklaşık 150 yıllık bir geçmişi olan tren turizmi uygulamalarının ilk şekli eğlence ve keşif amaçlıydı. 1870'lere gelindiğinde tren ile seyahatlerin amacı dağları veya kıyı manzaralarını görmek içindi. 1950'lerin başında ise eski trenler kullanılarak yapılan tren turizmi, daha çok geçmişi anımsama, yani nostalji amaçlı yapılan seyahatler şekline dönüştü. 1980'lerde ise hibrit bir seyahat şekli gelişti. Yerel ve lüks trenlerin kullanımı ile tarihsel ve keşif amaçlı seyahatler ortaya çıkmış (Blancheton ve Marchi, 2013:31) ve tren ile yapılan turist gezileri iki kategoride sınıflandırılmıştır. Bunlardan ilki kültürel değeri olan yüksek alanlara yapılan kısa seyahatlerdir. İkincisi ise önemli mesafeleri kapsayan gemi yolculuğu gibi yapılan otel trenlerdir (Gattuso vd., 2019: 2011-2013). Tren-oteller hem vagonların hem de hizmetin kalitesi açısından demiryolu ile gemi yolculuğu sunmak üzere önerilen trenlerdir. Bu tür teklifler, Güney Afrika'dan Kuzey Amerika'ya, Kuzey Avrupa'dan Sibirya'ya kadar dünyanın çeşitli yerlerinde mevcuttur (Thirumaran ve Raghav, 2017). 
Demiryolu turizmi heterojen olduğu için turistlerin demiryolu ile seyahat etme tercih nedenleri kişiden kişiye değişebilmekte ve bu seyahatten aldıkları tatmin düzeyi de aynı şekilde farklılık göstermektedir. Demiryolu turizmi tercih etme motivasyon unsurları da değişebilmektedir. Demiryolu turizmi, manzaraların keşfi, yaşayan mirasla temas, yeni yerler görme arayışı gibi nedenlerle yapılan rekreasyon faaliyetleridir (Blancheton ve Marchi, 2013:32). Eski buharlı trenlerle yapılan nostaljik seyahatler geçmişe duyulan özlemi gidermek amaçlı yapılan seyahatlerdir (Halsall, 2001). Günümüzde sosyal medyanın da etkisiyle oldukça popüler hale gelen tren yolculukları insanların renkli ve farklı bir deneyim yaşamalarına neden olur. Ortalama bir ya da iki gün süren tren yolculukları ile kentsel yaşamın yoğunluğundan ve stresinden kurtulmak isteyen turistler, kültürel, nostaljik ve doğal ortam deneyimlerini fotoğraf veya video çekerek sosyal mecralarda paylaşarak hayatlarına renk katarlar. Bu paylaşımlar tren seyahatlerine katılma isteğini artırmaktadır (Çakmak ve Altaş, 2018:391-392).

Türkiye'de demiryolu seyahatleri ile ilgili yapılan araştırmalara bakıldığında sayının yetersiz olduğu anlaşılmaktadır. Eser ve Asmadili (2019), Doğu Ekspres ile ilgili çalışmasında Kars kentinin ve Ani Harabelerinin kültürel öneminin ortaya çıkarılması ile daha da geliştirilebileceğini ifade etmişlerdir. Sünnetçioğlu vd., (2020) ve Doğan vd., (2018) tarafından yapılan çalışmalarda Doğu Ekspres tren seyahatlerinin son dönemdeki popülerliğinin nedenini sosyal medyada yapılan paylaşımlara bağlamış ve çalışmalarında sosyal medya üzerinden yapılan deneyim paylaşımlarının seyahat kararlarında etkili olduğunu belirlemişlerdir. Bingöl ve Kozak (2020) ise Doğu, Van Gölü ve Güney Kurtalan Ekspresleri konulu çalışmasında, tren seyahati tercih nedenlerinin yolda olmak, kültür, nostalji, manzara, ucuzluk gibi nedenlerle tercih edildiğini, hizmet kalitesinde bazı sorunların olduğunu ve aktivelerin yetersiz olduğunu tespit etmişlerdir.

\section{Dünyadaki Demiryolu Turizm Seyahatlerinin Değerlendirilmesi}

Dünyada çekici rotaları ile tren seyahat hizmeti sunan ülkelerin başında Fransa, Rusya, Avusturya ve İsviçre gelmektedir (Bingöl ve Kozak, 2020). Dünya'da nostaljik tren seyahati sunan pek çok kültürel rota vardır. Bunlara örnek verecek olursak, Avustralya'daki The Ghan, Rusyada'ki Trans Sibirya ve İsviçre'deki Glacier Ekspres önemli tren turizmi rotalarıdır. The Ghan tren seyahati rotası; Güney Avusturalya'dan başlar, kuzeyde yer alan Darwin'e kadar ulaşır. İsviçre Alplerini görme fırsatı sunan Glacier Ekspresi dünyanın en yavaş tren seyahatlerinden bir olarak kabul edilir. Seyahati boyunca 91 tünel ve 291 köprüden geçen bu seyahat treninin geniş pencereleri sayesinde Matterhon Dağ1 ve İsviçre Büyük Kanyonu gibi doğal manzaraların rahatça izlenmesi sağlanmıştır. Rusya' da bulunan Trans Sibirya Ekspresi ise dünyanın en çok ilgi gören tren seyahat rotalarından biridir. Moskova'dan başlayan tren seyahati tüm Rusya'yı dolaşmakta ve doğuda yer alan liman kasabası Vladivostok'a kadar devam etmektedir (www.momondo.com.tr). Uzak Doğu'yu Batı Avrupa'ya bağlayan bu tren rotası tarihte çeşitli isimler ile anılmıştır. Bunlar, Trans Sibirya Kara Köprüsü, Trans Sibirya Rotası ve Trans Sibirya Hattıdır (Liliopoulou vd., 2005). Bazı demiryolu hatları UNESCO tarafından Kültürel Dünya Miras Listesine alınan bazı demiryolu hatlarından biri Hindistan'ın Batı Bengal eyaletinde 1879-1881 yılları arasında inşa edilmiş, Darjeeling Himalayan Demiryolu'dur (https://en.wikipedia.org). Dünyanın önde gelen 12 demiryolu, güzergâhları ve mesafeleri ile ilgili bilgi Tablo 1'de gösterilmiştir. 
Tablo 1. Dünyanın Önemli Demiryolu Hatları

\begin{tabular}{|l|c|c|l|}
\hline Demiryolu Ad1 & $\begin{array}{c}\text { Mesafe } \\
\text { (Km) }\end{array}$ & Ülke & Güzergâh \\
\hline The Ghan & 2979 & Avustralya & Adelaide-Darvin \\
Glacier Express & 290 & İsviçre & Zermatt-St.Moritz \\
Trans Siberian Ekspres & 9289 & Rusya & Moskova-Vladivostok \\
Flam Railway & 30 & Norveç & Flam-Myrdal \\
TranzAlpine & 223 & Yeni Zelanda & Christchurch-Greymouth \\
The Jacobite & 135 & İskoçya & Fort William-Mallaig \\
Rocky Mountainer & 1398 & Kanada & Vancouver-Banff \\
Grand Canyon Railway & 105 & ABD & Williams-Grand Canyon National \\
Bergen Railway & 371 & Norveç & Park \\
Palace on Wheels & 3000 & Hindistan & Bergen-Oslo \\
Alishan Forest Railway & 86 & Tayvan & Yeni Delhi-Agra Chiayi \\
Doğu Ekspresi & 1310 & Türkiye & Ankara- Kars \\
& \multicolumn{3}{|l}{} \\
\hline
\end{tabular}

Kaynak: Yazar tarafından derlenmiştir.

Dünyada demiryolu turizm hizmeti sunan ve önemli tren yolculuklarından biri olan The Ghan Avusturalya'nın geniş alanlarından geçer. Her şey dâhil sistemi ile gold ve platinum şeklinde iki çeşit hizmet seviyesinde yiyecek ve içecek sunulur. Tren seyahati boyunca turistik çekiciliği olan yerlerde ekstra molalar verilir. Gidilen noktalardaki özel restoranlarda yemekler yenilir. Yolcuların tatil tadında bir seyahat geçirmesi için hizmetler planlanır (https://www.australia.com). Tek bir yolculukta dört mevsim yaşama imkânı sunan Glacier Ekspres tren yolculuğu esnasında beş yıldızlı otellerde sunulan bir hizmet anlayışı benimsenmiştir. Çok çeşitli ve zengin bir yeme- içme hizmeti sunulmaktadır. Tren vagonlarındaki tavana kadar varan pencere genişliği yolcuların seyahat esnasında geçtikleri noktalardaki manzaların keyfine varmalarını sağlayan önemli bir özelliktir. Çalışanların özenli seçilmesi hizmete verdikleri önemi ortaya koymaktadır (https://www.youtube.com/). Kanada Rocky Mountainer 2 gün süren lüks bir tren yolculuğudur. Tren vagonları çok iyi döşenmiş ve tavana kadar varan geniş camlarla kaplıdır. Yolculuk boyunca istenildiği zaman alınabilecek oldukça çeşidi bol bir yeme içme menüsü vardır. Geçilen güzergâhlarda tren personelleri tarafından bilgilendirme yapılmakta ve yolcuların eğlenceli zaman geçirebilmeleri için çeşitli etkinlikler düzenlenmektedir. Yolculuğu daha keyifli hale getirilebilmesi için çok iyi sunulan bir hizmet anlayışı benimsenmiştir (https://www.youtube.com/). Palace on Wheels 7 gün süren tren yolculuğu beş yıldız bir otel gibi hizmet sunan iyi döşenmiş vagonlara sahiptir. Hindistan'ının ve geleneklerinin iyi tanıtıldığı tren yolculuğu dünyada pek çok insan tarafından tercih edilen bir tren seyahatidir (https://www.youtube.com).

\section{Doğu Ekspres Tren Seyahati}

TCDD tarafından, cumhuriyetin ilk yıllarından itibaren Türkiye' de yapılan tren hatlarından biri olan Doğu Ekspres hattının inşasının tamamlanması aşamalı gerçekleşmiştir. İlk olarak 1927' de Ankara- Kayseri, ardından 1930'da Sivas, 1938'de Erzincan, 1939 ise Erzurum hatt1 tamamlanmıştır. Tamamlanan bu hat Ruslar tarafından daha önce inşa edilen Erzurum- Kars demiryoluna bağlanarak, Doğu Ekspres hattı oluşturulmuştur (Temizgüney, 2015). Doğu Ekspres rotası; Ankara, Kayseri, Sivas, Erzincan, Erzurum, Kars illerini kapsamaktadır. Doğu 
Ekspres TCDD'ye ait kompartımanlı bir seferdir. Ankara- Kars arası $1310 \mathrm{~km}$ olan yol yaklaşık 24 saatte tamamlanır (Kırtıloğlu, 2016).

Şekil.1 Doğu Ekspres Güzergâhı

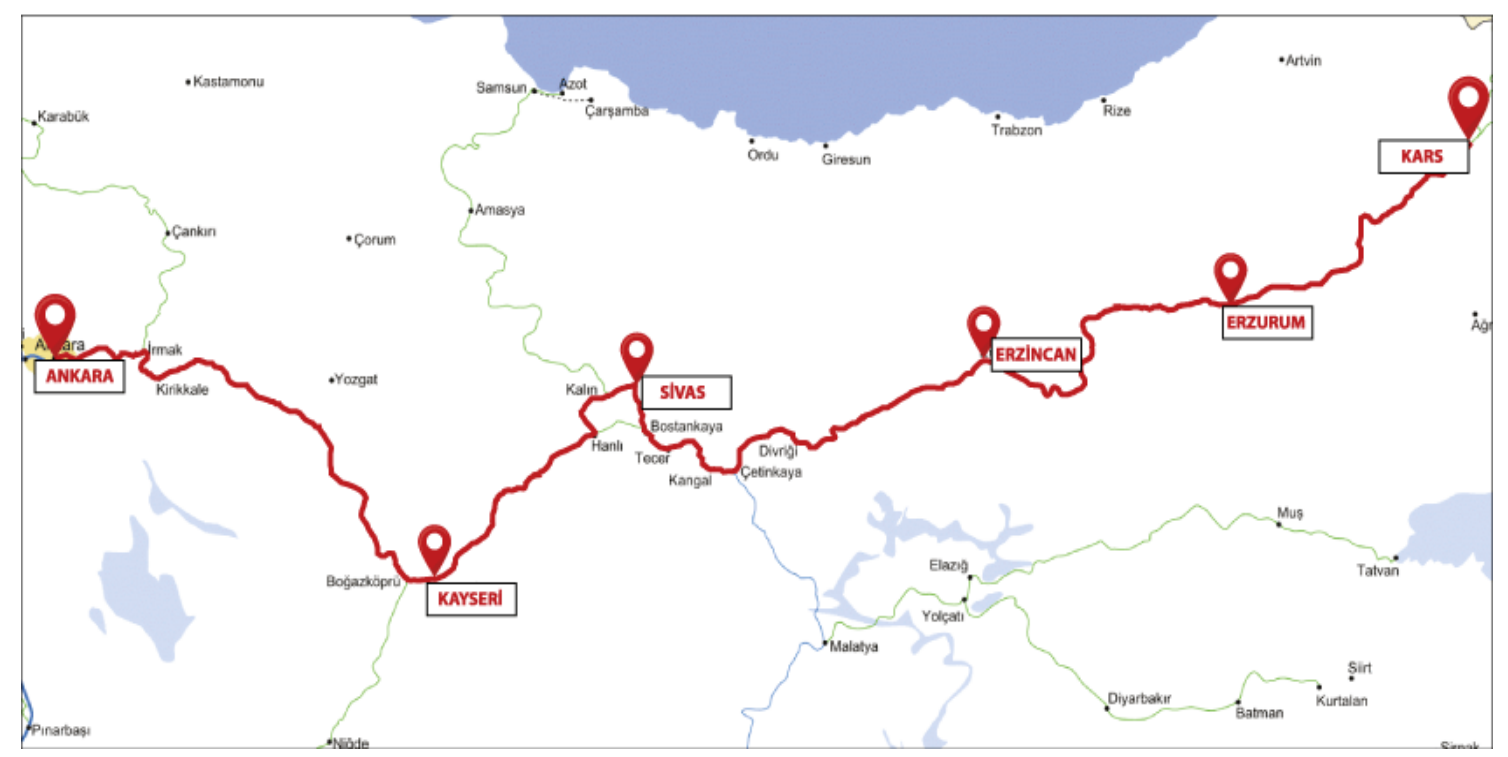

Kaynak: http://www.tcddtasimacilik.gov.tr/tren/dogu-ekspresi/

Covid-19 pandemisinden dolayı belli bir süre hizmet veremeyen bu hat yaklaşık $1910 \mathrm{~km}$ dir. Doğu Ekspres treni pulman, kompartımanlı örtülü kuşet, yemek ve yataklı olmak üzere çeşitli vagon tiplerinde hizmet vermektedir.

Pulman Vagon: Yolcuları rahat ettirebilmek için ergonomik tasarımlarla hazırlanmış bu vagon tipi, diğer vagon tiplerine göre daha ekonomiktir. Pulman vagon koltuk sistemi $2+1$ olarak döşenmiş ve koltuklar geriye yatırılabilir özellikte tasarlanmıştır. Koltuk aralarında açılıp katlanabilir masalar ile koltuk üstlerinde yolcuların bagajlarını koyabilecekleri alanlar mevcuttur. Seyahat esnasında koltuk kenarlarında yer alan prizlerle yolcular çeşitli elektronik eşyalarını şarj edebilmektedirler. Pulman vagonların her iki tarafında sadece pulman vagonlarla seyahat edenlerin kullanabilecekleri tuvaletler vardır. Evcil hayvanların taşınmasına izin verilen tek vagon tipidir.

Örtülü Kuşetli Vagon: Karşılıklı ikişer kişilik koltuğun yer aldığı, toplamda ise dört kişilik koltuğun (istenirse 4 kişilik yatak haline dönüştürülebilen) olduğu vagon tipidir. Vagon içerisinde bagaj bölümü, wc., lavabo ve prizler vardır. Örtülü kuşetli vagon, pulman vagonlara göre daha rahat ve kullanışlıdır, fakat evcil hayvan taşıma izni bu vagon tipinde yoktur.

Kompartıman Vagon: Ayrı bölümlerden oluşan bu vagon tipi içerisinde var olan ses ve 1sı yalıtımı sayesinde mevsime uygun bir ortam oluşturulur. Vagon, yolcuları nasıl rahat ettirebiliriz düşüncesiyle dekore edilmiştir. Bu nedenle yolculara güvenli, emniyetli ve eğlenceli bir seyahat imkânı sunar.

Yemekli Vagon: Tüm hijyen koşulları oluşturularak, tren ile seyahat eden tüm yolculara yeme-içme hizmeti sunmak için dizayn edilmiş vagondur. Yolcular tren seyahati boyunca istedikleri zamanda bu vagona gidip yeme-içme siparişi verebilir (http://www.tcddtasimacilik.gov.tr/).

Kış turizmi ve kültür turizmi gibi alternatif turizm faaliyetleri dâhilinde olan Doğu Ekspres tren seferleri, diğer ulaşım türlerine göre daha ucuz olmasından dolayı sosyal turizm faaliyetleri 
kapsamında değerlendirilebilir (Arslan, 2018). Özellikle son yıllarda sosyal medya üzerinde sıkça gündeme gelen Doğu Ekspres yolculuğu sıradan bir seyahat değil, farklı deneyimlerin yaşandığ bir yolculuk haline gelmiştir (Ceylan vd., 2018).

Dünyanın en güzel turistik rotalarından biri olan Doğu Ekspres, eski Ankara Garı'ndan hareket etmekte ve seyahat güzergâhı boyunca belli noktalarda yerel tur amaçlı uzun süreli duruşlar yapmaktadır. Ankara- Kars'a yolculuğu boyunca duruşlar, İliç (3 saat), Erzincan (2 saat 40 dakika), Erzurum (2 saat 40 dakika) şeklindedir. Kars'tan Ankara' ya gidişteki duruşlar ise Divriği (2 saat 36 dakika), Bostankaya- Sivas (3 saat 09 dakika) dır. Ankara'dan Kars'a varış yaklaşık 31 saat, Kars Ankara arası ise yaklaşık 30 saat sürmektedir (Turistik Doğu Ekspresi - TCDD Taşımacılık AŞ Genel Müdürlügü (www.tcddtasimacilik.gov.tr)

Şekil 2. Doğu Ekspres Treni

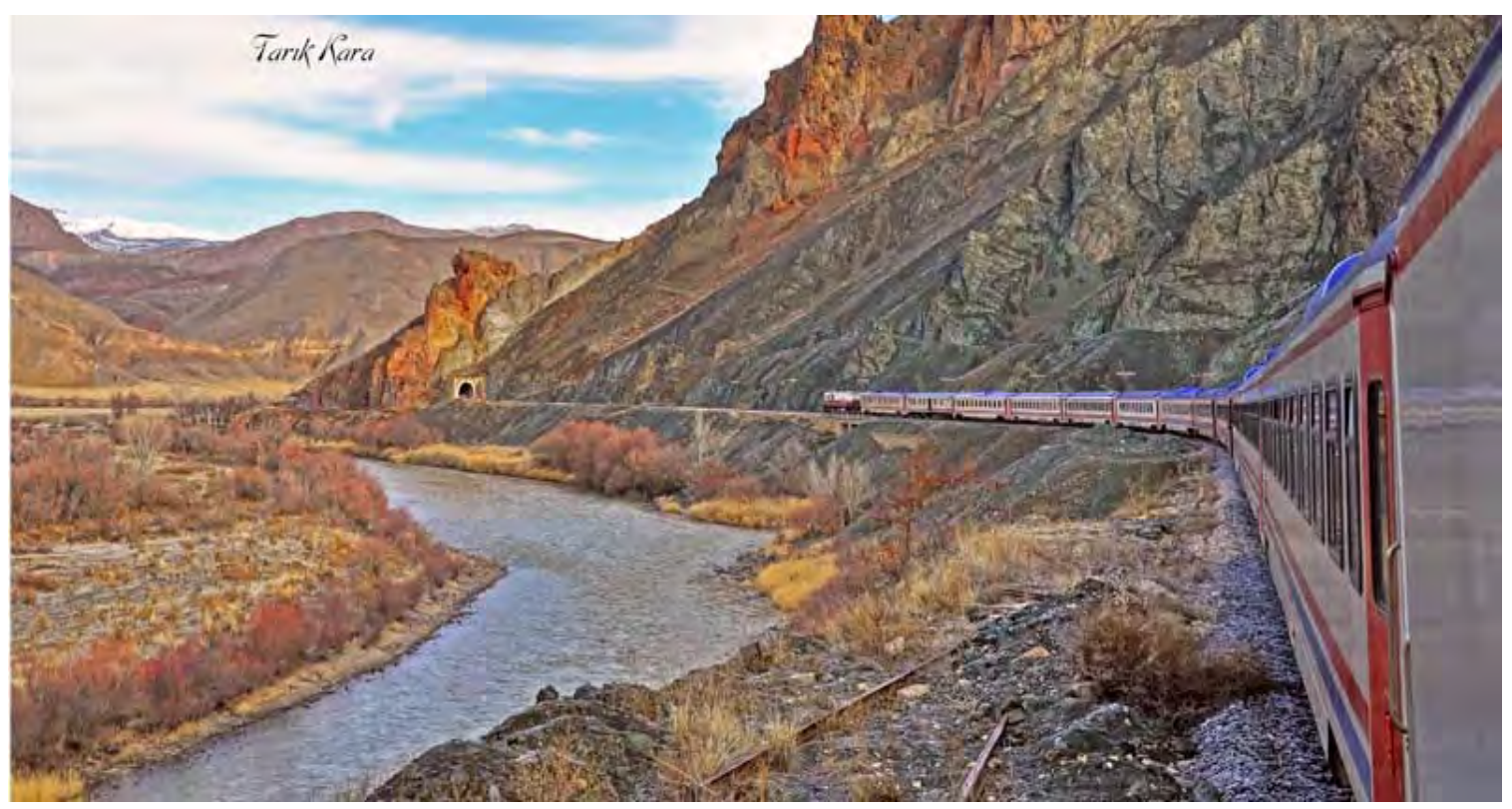

Kaynak: http://www.tcddtasimacilik.gov.tr/tren/dogu-ekspresi/

Doğu Ekspres sadece bir turistik tren seyahati değil, doğu illerini birbirine bağlayan bir demiryolu hattıdır (IHA, 2019). Doğu Ekspres Tren yolculuğu son yıllarda oldukça popüler bir kış aktivitesi haline gelmiştir (Kırtıloğlu, 2016). Bu durum tur şirketlerinin dikkatini çekmiş ve tur şirketi tarafından vagon kiralama ile pazarlanması mümkün hale gelmiştir. Tur şirketleri tarafından kiralanan vagonlar Doğu Ekspres trenine sonradan ilave edilebilmektedir. Bu vagonlar için seyahat fiyatına konaklama, yemek ve gezi hizmetleri de isteğe göre ilave edilmekte ve tur paket fiyatı belirlenmektedir (Bulut ve Eşitli, 2019).

\section{YÖNTEM}

$\mathrm{Bu}$ araştırmanın amacl, Turistik Doğu Ekspres treni ile Ankara'dan Kars'a yolculuk yapan kişilerin seyahat deneyimlerini ve yolculukları boyunca sunulan hizmetlerin kalitesini değerlendirmek ve Turistik Doğu Ekspres tren seyahatinin eşsiz bir deneyim haline getirilmesidir. Ayrıca; varsa eksikliklerin tespit edilip, daha iyi hizmet sunulması için önerilerde bulunmaktadır. Çalışmada verilerin derinlemesine ve farklı boyutlarda yorumlanabilmesi için nitel araştırma yönteminin daha uygun olacağ düşünülmüş, bu amaç doğrultusunda çalışma kurgulanmıştır. Nitel araştırma yöntemi sosyal bilimlerde gittikçe daha çok kullanılmaktadır (Karataş, 2015). İnsanların bakış açılarını, duygularını, öznel deneyimlerini ve algılarını ortaya 
koymak için ilgili kişilerle görüşme en etkili yöntemdir (Yıldırım ve Şimşek, 2008). Araştırmada nitel araştırma tekniğinin kullanılmasının bir diğer nedeni ise, katılımcıya sınırlama getirmeden rahat bir şekilde soruları yanıtlamasını sağlamaktır. Bu sebeple ilgili kişilerle görüşme yapmak için açık uçlu soruların da olduğu bir görüşme formu hazırlanmıştır Görüşmeler 25-28 Ocak 2019 yılında Turistik Doğu Ekspres ile Ankara- Kars seferine katılan, Kars'a iniş yapan ve görüşmeyi kabul eden 56 yolcu ile 25-35 dakika arası kalıcı görüşmeler gerçekleştirilmiştir.

Araştırmada, ilk etapta kavramsal yapı ve görüşmelerin veri analizi için bir çerçeve oluşturulmuş, sonrasında ise veriler düzenlenmiştir. Son aşamada ise veriler tanımlanarak, bulguların açıklanması, ilişkilendirilerek anlamlandırılması ve yorumlanması gerçekleştirilmiştir.

\section{BULGULAR}

Görüşmeler neticesinde elde edilen katılımcıların demografik ve seyahat bilgilerine yönelik değerlendirme sonuçları aşağıdaki gibidir.

\section{Katılımcıların Demografik ve Seyahat Bilgileri}

Demografik özellikler seyahat bilgileri cinsiyet, yaş, eğitim ve meslek, tren seyahatini çevreye tavsiye etme durumu, duraklarda kalış süresi yeterlilik ve yeme-içme hizmeti alma durumu Tablo 2' de mevcuttur. Bu tabloya göre, katılımcıların çoğunluğu 32'si (\%57) erkek; 24' ü (\%43) ise kadındır. Katılımcıların yaş aralığı (\%71) oranında 17- 40 arasında değişmektedir. Eğitim durumu bakımından üniversite mezun ve okuyor durumda olanların sayısı yarıdan fazladır (\%64). Katılımcıların 20'si (\%35) kamu çalışanı, 16'sı (\%29) öğrenci geri kalanlar ise özel sektör çalışanı ve çalışmayanlardan oluşmaktadır. Katılımcıların hepsi tren seyahatini şiddetle tavsiye etmektedir. Katılımcıların çoğunluğu trenin duraklarda bekleme süresini yeterli bulmamaktadır (\%66). Katılımcıların yarıdan fazlası durulan duraklarda yeme hizmeti almamaktadır (\%54).

Tablo 2. Katılımcıların Demografik ve Seyahat Bilgileri

\begin{tabular}{|c|c|c|}
\hline Demografik ve Seyahat Bulgular & (n) & $(\%)$ \\
\hline Erkek & 32 & 57 \\
\hline Kadın & 24 & 43 \\
\hline \multicolumn{3}{|l|}{ Yaş } \\
\hline $17-25$ & 18 & 32 \\
\hline $26-40$ arasi & 22 & 39 \\
\hline $41-50$ aras 1 & 7 & 13 \\
\hline 51 ve üstü & 9 & 16 \\
\hline \multicolumn{3}{|l|}{ Eğitim } \\
\hline İlköğretim & 4 & 7 \\
\hline Lise & 9 & 16 \\
\hline Önlisans ve Lisans (mezun veya okuyor) & 36 & 64 \\
\hline Lisansüstü & 7 & 13 \\
\hline \multicolumn{3}{|l|}{ Meslek } \\
\hline Kamu çalışanı & 20 & 35 \\
\hline Özel sektör & 14 & 25 \\
\hline Öğrenci & 16 & 29 \\
\hline Çalışmıyor & 6 & 11 \\
\hline \multicolumn{3}{|c|}{ Tren seyahatini çevreye Tavsiye Etme Durumu } \\
\hline Evet, tavsiye ediyorum & 56 & 100 \\
\hline Hayır, tavsiye etmiyorum & 0 & 0 \\
\hline \multicolumn{3}{|c|}{ Durulan İstasyonlarda Kalış Süresi Yeterlilik Durumu } \\
\hline Evet, yeterli & 19 & 34 \\
\hline Hayır, yetersiz & 37 & 66 \\
\hline \multicolumn{3}{|c|}{ Durulan İstasyonlarda Yeme Hizmeti Alma Durumu } \\
\hline Evet, aldım & 26 & 46 \\
\hline Hayır, almadım & 30 & 54 \\
\hline TOPLAM & 56 & 100 \\
\hline
\end{tabular}




\section{Doğu Ekspres Tren Seyahati Tercih Edilme Nedenleri}

Tren seyahatine katılma tercih nedeniniz nedir sorusuna verilen cevaplar incelendiğinde katılımcıların en çok sıraladıkları nedenler doğal güzellik (30/56), turistik gezi (27/56), reklam (21/56), ucuzluk (15/56), nostalji (12/56), güvenli (11/56), merak (9/56), konforlu (6/56) olarak belirlenmiştir. Verilen cevaplar kelime bulutu şeklinde aşağıdaki Şekil 3'te gösterilmiştir.

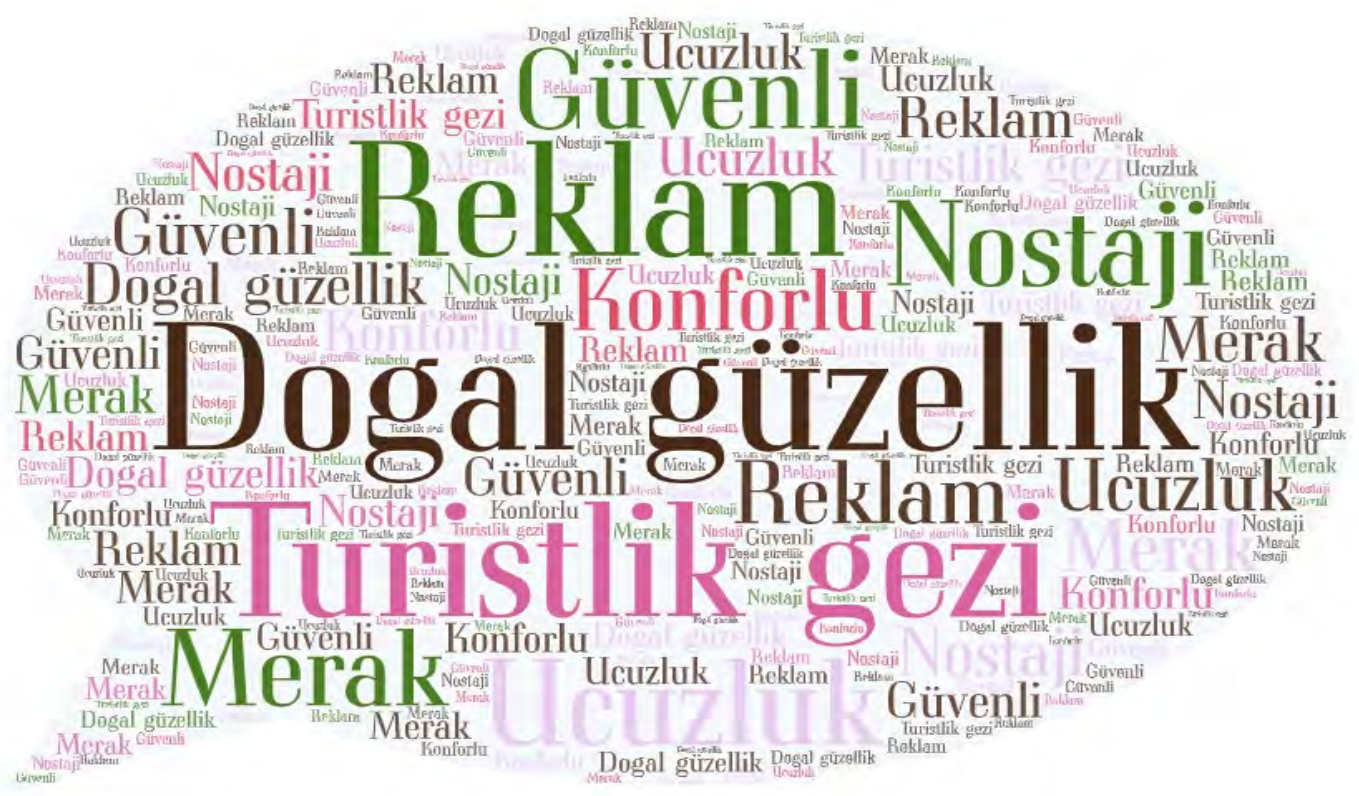

Şekil 3: Tren Seyahati Tercih Nedenleri

Doğal güzellik, tren yolculuklarının temel motivasyon unsuru olarak görülen bir kavramdır. Yolculuk anında geçilen noktaların doğal güzelliklerini, manzaraları izlemek tren yolculuklarının en önemli katılma nedeni olarak belirlenmiştir.

K: "Trenin geçtiği yerlerdeki doğal güzelliklere hayran kaldım. Manzaralardan çok etkilendim. Yanıma aldığım fotoğraf makinemle doğal manzaraları fotoğrafladım. Zaten tren seyahatini tercih etme nedenimde bu doğal ortamı yaşamak ve fotoğraflamakdı".

K: Gerçekten yaşanması gereken bir yolculuk geçirdim. Geçtiğimiz noktalardaki doğal güzellikler ve manzaralar beni büyüledi. Tren seyahatine katılma nedenim doğal güzellikleri görmek içindi. Dă̆ manzaraları, geniş düzlükler, kırsal köy yaşamları, geçtiğimiz her nokta tam kartpostallı manzaralardı.

Yolculuk boyunca değişen manzaraları izlemek, yolculuktan alınan keyfi artırmaktadır (Halsall, 2001; Alkan, 2018; Bingöl ve Kozak, 2020). Tren yolculuğu esnasında geçilen yerdeki doğal güzellikler, manzaralar, kırsal köy, dağ manzaraları ve doğal yaşam manzaraları bu yolculukların tercih edilmesinde en önemli neden olarak görülmektedir.

Turistik gezi; tren yolculuğunun ikinci sırada tercih nedeni olarak belirlenmiştir. Farklı turistik deneyim yaşamak isteyen insanlar için tren yolculuğu da önemli bir alternatiftir.

K: Daha önce böyle bir geziye katılmamıştım. Ben çok sık turisttik gezi yaparım. Farklı deneyimler yaşamak benim hobilerim arasındadır. Tren seyahati deneyimi de yaşamak istedim ve bu nedenle bu turistik geziye katıldım. 
İnsanlardaki faklı deneyim yaşama isteği, bu tip gezilere insanların katılmasını sağlayan önemli bir neden olarak görülmekte ve insanların seyahat tercihlerini etkilemektedir.

Araştırmada tren yolculuklarının tercih nedenleri arasında reklamın da etkisinin olduğu kabul görmüştür. Özellikle sosyal medyada yapılan paylaşımlar bu yolculuğa katılma nedenleri arasında yer almıştır.

K: Doğu Ekspres tren seyahatini sosyal medya reklamlarında gördüm. Yapılan reklam paylaşımlarından çok etkilendiğim için bu seyahate katılmaya karar verdim.

Doğu Ekspres Tren seyahatlerinin son dönemdeki popülerliğinin nedenini sosyal medyada yapılan deneyim paylaşımlarının seyahat kararlarında etkilidir (Sünnetçioğlu vd., 2020; Doğan vd., 2018).

Nostalji, ucuzluk, konfor, merak ve güvenli olması da katılma nedenleri olarak belirlenmiştir.

K: Trenin tasarımı bana geçmişi hatırlattı̆̆ı için bu seyahate katılmak istedim. Benim çocukluğum köyde geçti. Köyümüzün içinden kara tren geçerdi ve bizim köy kara trenin durduğu bir durakt. Çocukluğumda tren ile çok yolculuk yaptım. Ama uzun süredir trene binmemiştim. Bu özlemi bu seyahat ile gidermek için katıldım.

K: Diğer ulaşım araçlarına göre tren ile seyahat etmek çok ucuz. Bilet fiyatları uygun olduğu için treni tercih ettim. Dönüş için de bilet aldım. Hem geziyorum hem de istediğim yere uygun fiyat ile gidiyorum.

K: Ulaşım araçlarn içerisinde en güvenlisi trenler ile yapılan seyahatlerdir. Kaza oranlarına bakıldı̆̆ında bunu görmek mümkün.

\section{Doğu Ekspres Tren Seyahati Hizmetlerindeki Yetersizlikler}

Katılımcılara seyahatleri boyunca aldıkları hizmetlerle ilgili yetersizlikler sorulduğunda, en çok tekrar edilen cevaplar tuvaletlerin temizliği (18/56), Lavobolar dar (12/56), vagonlardaki prizler, duraklarda durma süresi yetersiz (8/56), Hizmette herhangi bir eksiklik yok (8/56), havalandırma eksik, sigara içme alanı yok (7/56), vagonlarda ışıklandırma eksik (6/56), Yüksek ses (5/56), yemeiçme yetersiz, odalar çok dar, camlar çok küçük (4/56), Koridorlar dar ve soğuk (2/56) şeklinde sıralanmıştır.

Tablo 3. Tren Seyahati Hizmet Yetersizliği

\begin{tabular}{|l|l|l|c|}
\hline Hizmet Yetersizliğ $i$ & Frekans & Hizmet Yetersizliği & Frekans \\
\hline Tuvalet Temizliği Yetersiz & 18 & Çalışanlar kaba ve sinirli & 7 \\
\hline Sigara İçme alanı yok & 7 & Hizmet yeterli & 8 \\
\hline Lavabolar dar & 12 & Havalandırma yetersiz & 7 \\
\hline Duraklarda durma süresi az & 8 & Koridorlar dar ve soğuk & 2 \\
\hline Vagonlardaki prizler eksik & 8 & Yüksek ses & 5 \\
\hline Vagonlarda 1şıklandırma eksik & 6 & Yeme- içme yetersiz & 4 \\
\hline Camlar çok küçük & 4 & Odalar çok dar & 4 \\
\hline
\end{tabular}

Doğu Ekspres tren seyahati hizmetleri ile ilgili yetersizlikler sorusuna en çok verilen cevap lavabo temizliği ve lavaboların küçük olmasıdır. Seyahatin uzun olması lavaboların daha çok kullanılmasına gerektirmektedir. Bu durum sürekli bir temizlik ihtiyacı doğurmaktadır. Yetersiz temizlik müşteri memnuniyetsizliğine neden olmuştur. 
K: Seyahat çok güzeldi. Bizim en çok sorun yaşadığımız durum tuvaletlerin temizlĭgi ve bakımıydı. Tuvaletler hiç temiz değildi. Lavabolar çok dardı. Tuvaletler ile ilgi önlem alınması gerekir.

Hizmet alanlarında temizlik yolcuların en çok önemsediği konudur. Araştırmaya katılan yolcuların büyük bir çoğunluğu tuvalet temizliği ve tuvaletlerin yetersizliği ile ilgili görüşlerini dile getirmişlerdir. Yolcuların rahat edebileceği hijyenik koşulların sağlanması yapılan hizmetin en önemli parçasıdır.

Tren teçhizatları ile ilgili bazı yetersizliklerin olduğu yolcular tarafından belirtilmiştir. Vagonlarda prizlerin eksik olduğu, ışıklandırma ve havalandırma sistemlerinde eksikler olduğu, camların küçük, koridorlar ve odaların dar olduğu ile ilgili bazı eksiklikler yolcular tarafından belirtilmiştir.

K: Vagonlarda prizler yolcular için yetersizdi. İlaveten çoğu priz çalışmıyordu. Seyahatin uzun olması prizlere olan ihtiyact artirmaktadir.

K: Işıklandırma ve havalandırma sistemleri böyle uzun bir yolculuk için yetersiz kalmıştır.

K: Geçtiğimiz yerlerdeki doğal güzellikleri ve doğa manzaralarım daha geniş bir camdan izlemek isterdim. Camlar bence küçük. Dünyadaki turistik trenleri biraz araştırdım. Trenlerde dış manzarayı izlemek için çok geniş camlar kullamılmış.

K: Böyle uzun bir tren seyahati için odalarda dar tasarlanmış, daha geniş vagonlar kullanılmalıdır.

Tren seyahati esnasında yaşanan küçük gibi görünen bir olumsuzluk bile seyahatin tamamını etkileyecek bir sonuç doğurabilir. Prizlerin çalışmıyor olması, ışıklandırma ve havalandırma sistemlerinin yetersizliği ve odalar ve vagonların çok dar dizayn edilmesi yolcuları olumsuz etkilemiştir.

Bir gündüz, bir gece süren tren seyahati ile ilgili hizmet yetersizliklerinden bazıları ise istasyonlarda durma süresinin yetersiz olması, yeme-içme hizmetinin yetersizliği ve çalışanların kaba davranışları ile ilgilidir.

K: Çalışanlar yolculara davranışları ile ilgili eğitilmelidir. Çünkü sorduğumuz sorulara çok kabaca cevaplar ald $k$.

K: Durulan duraklar yeme içme hizmeti almak için yetersiz. Bence molalar uzun olmalıdır.

K: Tren içinde verilen yeme-içme hizmeti bence çok yetersiz. İyi ki evden yemek için bir şeyler getirmişiz.

Yaklaşık 30 saat süren bir seyahat boyunca yemek, mola sürelerinin azlığı ve çalışanların davranışlarındaki nezaketsizlik bazı yolcuların yetersiz gördüğü hizmetlerdir.

\section{Kars'ta Katılmak İstenen Turistik Aktiviteler}

Katılımclara Kars'ta ne tür aktivitelere katılacaksınız sorusuna verilen cevaplar incelendiğinde Sarıkamış kayak merkezine gitmek 36/56, Yöresel Mutfağı deneyimlemek 12/56, Çıldır gölünde kızağa binmek 8/56 olduğu belirlenmiştir.

K: Kars'ın doğası çok güzel, Kars'a indiğimizde çok farklı duygular yaşadım. Ortamdan çok etkilendim. Özellikle Kars Sarıkamış Kayak Tesislerine gidip, orada kaymak istiyorum. Tesislerin kar kalitesi ve manzarası çok güzelmiş. 
K: Son dură̆ı Kars olan Doğu Ekspres turistik tren seyahatleri önemli turistik değgere sahiptir. Kars'a tren ile turist akışı sağlayacak bu tren rotası daha cazip hale getirilmelidir. Kars pek çok medeniyetin izlerini taşıyan arkeolojik bir şehirdir. Doğası, doğal manzaları, tarihi mekânları ve gastronomisi ile cazip bir şehirdir.

K: Sosyal medyada gördüğüm atl kızaklara binmek istiyorum. Gölün buzunu kırarak tutulan balıklardan yemek istiyorum.

K: Doğu Ekspres treni bence özellikle Kars için çok önemli bir turizm potansiyeli taşıyor. Tren seyahatinin hizmet ile ilgili bazı eksiklikleri var. Bunlar giderilir ve daha profesyonel hizmet sunulursa bu turistik rota gelecekte çok popüler olacaktır. Ben seyahat boyunca çok güzel deneyimler yaşadım, çok eğlenceli anlar geçirdim. Yaşanan bazı sıkıntılara rağmen seyahat çok güzeldi.

Kafkas Coğrafyasının bir parçası olan (Bingöl, 2011) Kars İlinin jeopolitik konumu, günümüze kadar pek çok kültür ve medeniyetin etkisi altında kalmasına neden olmuştur (Demir, 2017). Pek çok medeniyetin izini taşıyan Kars ili görülmesi gereken bir şehirdir. Özellikle Sarıkamış Kayak merkezi, Çıldır Gölü ve yöresel yemekleri katılımcıların deneyimleme istekleri arasındadır.

\section{TARTIŞMA, SONUÇ ve ÖNERİLER}

Bu çalışmanın amacı, Turistik Doğu Ekspres treni ile Ankara'dan Kars'a yolculuk yapan kişilerin seyahat deneyimlerini ve yolculukları boyunca sunulan hizmetlerin kalitesini değerlendirmek ve Turistik Doğu Ekspres tren seyahatinin eşsiz bir deneyim haline getirilmesidir. Ayrıca; varsa eksikliklerin tespit edilip, daha iyi hizmet sunulması için önerilerde bulunmaktır. Bu kapsamda Doğu Ekspres tren seyahati tavsiye etme durumu, istasyonlardaki kalış süresinin yeterlilik durumu, istasyonlardaki yeme hizmeti alma durumu, Doğu Ekspres tren seyahati tercih edilme nedenleri, Doğu Ekspresi tren seyahati hizmetlerindeki yetersizlikler ve Kars ilinde katılmak istenen turistik aktiviteler nelerdir belirlenmiştir. Araştırma kapsamında 56 kişinin görüşüne başvurulmuştur.

Tren yolculuklarına katılanlar çoğunlukla gençlerdir. Yolcuların çoğunluğu erkek olsa da kadın yolcular da (\%43) önemli bir oranda bu yolculuğa katılmıştır. Başka bir ifade ile tren yolculuğuna katılanların büyük bir çoğunluğu gençtir ama cinsiyet konusunda büyük bir farklılık yoktur. Benzer şekilde Bingöl ve Kozak (2020) de gençlerin tren yolculuklarını daha çok tercih ettiği; fakat cinsiyet konusunda büyük bir farklılık olmadığını belirlemişlerdir. Ĕgitim durumu bakımından üniversite mezun ve okuyor durumda olanların sayısı yarıdan fazladır. Katılımcıların hepsi tren seyahatini şiddetle tavsiye etmektedirler. Katılımcıların çoğunluğu trenin duraklarda bekleme süresini yeterli bulmamakta ve kalış sürelerinin artırılması gerektiğini düşünmektedirler. Katılımcıların yarıdan fazlası durulan duraklarda yeme hizmeti almamaktadır. Tren de sunulan yemek hizmetinin de yetersiz olduğunu ifade ettikleri için, buradan yolcuların yanlarında yemek ve içecek getirdiklerini söylenebilinir.

Yolculuk boyunca değişen manzaraları izlemek, yolculuktan alınan keyfi artırmaktadır (Halsall, 2001; Alkan, 2018; Bingöl ve Kozak, 2020). Tren yolculuğu esnasında geçilen yerdeki doğal güzellikler, manzaralar, kırsal köy, dağ manzaraları ve doğal yaşam manzaraları bu yolculukların tercih edilmesinde en önemli neden olarak görülmektedir. Tren yolculuğunun ikinci sırada tercih nedeni olarak belirlenen turistik gezi, farklı turistik deneyim yaşamak isteyen insanlar için önemli bir alternatiftir. İnsanlardaki faklı deneyim yaşama isteği, bu tip gezilere katılımı etkileyen önemli bir neden olarak görülmektedir. 
Araştırmada tren yolculuklarının tercih nedenleri arasında reklamın da etkisinin olduğu kabul görmüştür. Özellikle sosyal medyada yapılan paylaşımlar bu yolculuğa katılma nedenleri arasında yer almıştır. Sünnetçioğlu vd., 2020 ve Doğan vd., 2018 Doğu Ekspres tren seyahatlerinin son dönemdeki popülerliğinin nedenini sosyal medyada yapılan deneyim paylaşımlarının seyahat kararlarında etkilediği sonucu ile örtüşmektedir.

Tren yolculuklarının seçimini etkileyen diğer nedenler ise nostalji, ucuzluk, konfor, merak ve güvenli olma olarak belirlenmiştir. Nostalji yaşamak için de tercih edilen tren yolculukları esnasında duraklar ve varış noktalarındaki yaşayışlar tren yolculuklarının seçimini etkilemiştir. Allis vd., (2016) göre eski yaşam tarzlarını hatırlatan nostaljik trenler, kültür unsurlarını yansıtır.

Doğu Ekspres yolculuğunu başkalarına şiddetle tavsiye eden yolcular, seyahat esnasındaki hizmetlerde bazı yetersizlikler olduğunu ifade etmişlerdir. Doğu Ekspres tren seyahati hizmetleri ile ilgili yetersizlikler nelerdir sorusuna en çok verilen cevap lavabo temizliği ve lavaboların küçük olmasıdır. Seyahatin uzun olması lavaboların daha çok kullanılmasına gerektirmektedir. $\mathrm{Bu}$ durum sürekli bir temizlik ihtiyacı doğurmaktadır. Yetersiz temizlik müşteri memnuniyetsizliğine neden olmuştur. Hizmet alanlarında temizlik yolcuların en çok önemsediği konudur. Araştırmaya katılan yolcuların büyük bir çoğunluğu tuvalet temizliği ve tuvaletlerin yetersizliği ile ilgili görüşlerini dile getirmişlerdir. Yolcuların rahat edebileceği hijyenik koşulların sağlanması yapılan hizmetin en önemli parçasıdır. Ortalama 30 saat süren tren seyahati ile ilgili hizmet yetersizliklerinden bazıları ise istasyonlarda durma süresinin yetersiz olması, yeme-içme hizmetinin yetersizliği ve çalışanların kaba davranışları ile ilgilidir. Bingöl ve Kozak (2020) Doğu, Kurtalan ve Van Gölü Ekspresleri ile ilgili yapmış olduğu çalışmada hizmet kalitesi ile ilgili eksiklerin olduğu yönünde tespitleri vardır. Kars'ın turistik çekiciliği yüksek olan özellikle Sarıkamış Kayak merkezi, Çıldır Gölü ve yöresel yemekleri katılımcıların deneyimleme istekleri arasındadır.

Tren teçhizatları ile ilgili bazı yetersizliklerin olduğu yolcular tarafından belirtilmiştir. Vagonlarda prizlerin eksik olduğu, ışıklandırma ve havalandırma sistemlerinde eksikler olduğu, camların küçük, koridorlar ve odaların dar olduğu ile ilgili bazı eksiklikler yolcular tarafından belirtilmiştir.

Dünyadaki önemli tren yolculuklarına baktığımız zaman müşteri memnuniyeti yönlü uygulamaların olduğu görülmektedir. Örneğin The Ghan Avusturalya'nın geniş alanlarından geçen tren seyahati boyunca turistik çekiciliği olan yerlerde ekstra molalar verilir. Gidilen noktalardaki özel restoranlarda yemekler yenilir. Yolcuların tatil tadında bir seyahat geçirmesi için hizmetler planlanlanır. Glacier Ekspres tren yolculuğu esnasında beş yıldızlı otellerde sunulan bir hizmet anlayışı benimsenmiştir. Çok çeşitli ve zengin bir yeme- içme hizmeti sunulmaktadır. Tren vagonlarındaki tavana kadar varan pencere genişliği yolcuların seyahat esnasında geçtikleri noktalardaki manzaların keyfine varmalarını sağlayan önemli bir özelliktir. Çalışanların özenli seçilmesi hizmete verdikleri önemi ortaya koymaktadır. Kanada Rocky Mountainer tren vagonları çok iyi döşenmiş ve tavana kadar varan geniş camlarla kaplıdır. Yolculuk boyunca istenildiği zaman alınabilecek oldukça çeşidi bol bir yeme içme menüsü vardır. Geçilen güzergâhlarda tren personelleri tarafından bilgilendirme yapılmakta ve yolcuların eğlenceli zaman geçirebilmeleri için çeşitli etkinlikler düzenlenmektedir. Yolculuğu daha keyifli hale getirilebilmesi için çok iyi sunulan bir hizmet anlayışı benimsenmiştir. Palace on Wheels tren yolculuğu beş yıldız bir otel gibi hizmet sunan iyi döşenmiş vagonlara sahiptir. Hindistan'ının ve geleneklerinin iyi tanıtıldığı tren yolculuğu dünyada pek çok insan tarafından tercih edilen bir tren seyahatidir. 
Dünyada faaliyet gösteren yukarıda özelliklerini sıraladığım tren yolculukları ile yarışabilecek düzeyde olan Doğu Ekspres treninde de dünyadaki örneklerinde olduğu gibi hizmetler sunulabilir. Bu amaçla, Türkiye'den ve dünyadan pek çok yolcu çekebilecek bir kapasiteye sahip bu rotayı daha cazip hale getirebilmek için bazı öneriler sunulmuştur.

> Duraklarda ve varış noktalarındaki kalış süreleri artırılarak, durulan noktaların kültürel özelliklerini yansitacak farklı alternatifler sunulabilir.

$>$ Seyahat esnasında yolcuların eğlenceli zaman geçirebilmesi için çeşitli aktiviteler düzenlenebilir.

> Geçilen yerler ile ilgili sanki bir tura katılmış gibi yolcular bilgilendirilebilir.

$>$ Tren yemek vagonu menüsü çeşitlendirilebilir. Yolcuların yanlarında erzak getirmelerine ihtiyaç duymayacakları şekilde yeniden eklemeler yapılabilir.

$>$ Farklı gelir gruplarına hitap edilecek şekilde vagonlar düzenlenebilir.

$>$ Tren rotasında yer alan turistik çekiciliği fazla olan yerlerde ekstra molalar verilip, yolculuk renklendirilebilir.

$>$ Tren çalışanlarının seçiminde özenli davranılmalı, müşteri davranışı ile ilgili sürekli eğitim verilmelidir. Unutulmamalıdır ki hizmetin kalitesini etkileyen önemli etkenlerden biri çalışanların tavır ve tutumlarıdır.

$>$ Dünyadaki örneklerine bakılarak, iyi döşenmiş tren vagonları eklenebilir.

> Tren yolculuklarının en çok tercih nedeni manzaraların keşfidir. Geçilen yerlerdeki doğal manzaların keyfine daha çok varılabilmesi için camları daha büyük vagonlar Doğu Ekspres trenine eklenebilir.

Bu öncü çalışma ile Doğu Ekspres tren yolculuğundaki hizmetlerin kalitesi değerlendirilmeye çalışılmıştır. Görüşmeyi kabul eden kişilerin eşsiz bir deneyim olarak nitelendirdikleri bu yolculuğun daha çok tercih edilebilir hale getirilmesi için başka çalışmalara da ihtiyaç vardır. Turistik Doğu Ekspres tren seyahatleri kırsal doğu illerinde önemli bir ekonomik canlılık yaratmıştır. Ekonomik olarak dezavantajlı bu bölgenin kalkındırılması için yapılacak Turistik Doğu Ekspres tren rotası Nahcivan özerk cumhuriyetine uzatıla bilinirse daha çekici hale gelebilir. Azerbaycan Cumhuriyeti ile Ermenistan Cumhuriyeti arasında 2020 yılının son aylarında Karabağ' da ki savaşın ardından yapılan anlaşma gereği, Azerbaycan Cumhuriyetine bağlı, Nahcivan Özerk Cumhuriyeti ile Azerbaycan'ın diğer bölgelerine geçişi sağlayacak "Zengezur" koridorunun açılacak olması, bu hattın geliştirilmesi ve daha cazip hale getirilmesinde önemli bir avantaj sağlayabilir. Zira bahsi geçen o coğrafyada, turizm açısından çok önemli yerlerin varlığı bilinmektedir. Bu durum Türk dünyası ile bağlantıyı sağlayabilmek açısından, stratejik bir önemi de beraberinde getirmektedir.

\section{KAYNAKÇA}

Aslan, H. (2018). Alternatif Turizmin Bölge Ekonomisi Üzerindeki Etkisi: Samsun Örneği, Yüksek Lisans Tezi, Muğla Sıtkı Koçman Üniversitesi, Muğla.

Alkan, A. (2018). Alternatif bir turizm rotası: Kurtalan Ekspresi. Journal of Gastronomy Studies, 6(4): 1016-1038.

Allis, T., Fraga, C. and Velazquez, M. (2016). Railway for tourism in South America: An approach on its uses. Journal of Traffic and Transportation Engineering, 4: 339-349.

Blancheto, B and Marchi, J, J. (2013). The Three Systems of Rail Tourism: French Case. Tourism Management Perspectives, 5: 31-40. 
Bingöl, S ve Kozak, M. (2020). Turistik Tren Yolculuklarını Nostaljik Yaklaşım: Doğu, Güney Kutalan ve Van Gölü Ekspresleri, Journal of Recreation and Tourism Research 7(3): 325-349.

Bingöl, A. (2011). Kars ve Çevresinde Demir Çağı Yerleşmeleri. Sosyal Bilimler Enstitüsü Dergisi, 8: $20-40$.

Buluk, B ve Eşitli, B. (2019). Batıdan Doğuya Yavaş Seyahat: Doğu Ekspresi'nin Kars'ın Sürdürülebilir Turizm Gelişimine Etkisi, Ahi Evran Üniversitesi Sosyal Bilimler Enstitüsü Dergisi, 5(2): 159-176.

Ceylan, V., Ceylan, F. ve Yaman, M. (2018) 70 Yll Sonra Gelen Değişim: Doğu Ekspresi Yolculuğunun Gastronomi Turizmi Kapsamında Değerlendirilmesi, I. Uluslarası Turizmde Yeni Jenerasyonlar ve Yeni Trendler Konferansı Bildiriler Kitabı, 70 (2018): 135-144.

Çakmak, V. ve Altaş, A. (2018). Sosyal Medya Etkileşiminde Tren Yolculukları: Doğu Ekspresi ile İlgili Youtube paylaşım Videolarının Analizi, Journal of Tourism and Gastronomy Studies, 6(1): 390408.

Demir, M. (2017). Doğal ve Beşerî Özellikleriyle Kars İlindeki Turizm Faaliyetlerinin Durumu, Marmara Coğrafya Dergisi, 35: 134-154.

Doğan, M., Pekiner, B. ve Karaca, E. (2018). Sosyal Medyanın Turizm ve Turist Tercihlerine Etkisi: Kars Doğu Ekspres Örneği. Seyahat ve Otel İşletmeciliği Dergisi, 15(3): 669-683.

Dünyanın Önemli Tren Turizmi Rotaları: https://www.momondo.com.tr/discover/trenleyolculuk> (Tarih.06.11.2020).

Eser, E. ve Asmadili, V, U. (2019). Bir Kültür Mozaiği olan Ani Kentine Götüren Raylar: Turistik Doğu Ekspresi, Akademik Tarih ve Düşünce Dergisi. 6(4), 2132-2166.

Excellence Class- Glacier Express: https://www.youtube.com/watch?v=zALXRoysJA0> (Erişim Tarihi: 08.02.2021).

Economic Impact Reports, (2019). https://wttc.org/Research/Economic-Impact> Erişim Tarihi:14.02.2021.

Gattuso, D., Cassone, G, C. and, M. (2019). Transport- Tourism Integrated Policies. A Luxury Train in A Multimodal Corridor Along the Italian Ionian Coast to Support Economic Development, Proceedings of the Multidisciplinary Academic Conference. (Erişim Tarihi: 07.02.2021).

Halsall, D. (2001). Railway Heritage and the Tourist Gaze: Stoomtram Hoorn-Medemblik, Journal of Transport Geography, 9: 151-160.

Henderson, J. (2011). Railways as Heritage Attractions: Singapore's Tanjong Pagar station, Journal of Heritage Tourism, 6(1), 73-79.

Holloway, C and Taylor, N. (2006). The Business of Tourism. Harlow. USA: Prentice Hal.

https://en.wikipedia.org/wiki/Darjeeling_Himalayan_Railway> Erişim Tarihi: 14.02.2021.

Jensen, R. (1999). The Dream Society (How the coming shift from information to imagination will transform your business), New York: McGraw-Hill.

IHA (2018). Kars doğu ekspresi bilet fiyatları / doğu ekspres nereden ve kaçta kalkar? (Doğu Ekspres nereye gider). http://www.iha.com.tr/haber-kars-doguekspresi-bilet-fiyatlari-doguekspres-nereden-ve-kacta-kalkar-dogu-ekspres-nereye-gider698387.> (Erişim Tarihi: 10.02.2021). 
Karataş, Z. (2015). Sosyal Bilimlerde Nitel Araştırma Yöntemleri, Manevi Temelli Sosyal Hizmet Araştırmaları Dergisi, 1(1): 1-2.

Kırtıloğlu, G. (2016). Doğu ekspresi ile Kars seyahati. 10.02.2021 tarihinde https://www.turna.com/blog/dogu-ekspresi-ile-kars-seyahati adresinden erişilmiştir. Erişim Saati: 12:53.

Larsen, J. (2001). Tourism mobilities and the travel glance: experiences of being on the move, Scandinavian Journal of Hospitality and Tourism, 1(2), 80-98.

Liliopoulou, A., Roe, M. and Pasukeviciute, I. (2005). Trans-Siberian Railway: From Inception to transition. European Transport, 29.46-56.

Modern Turizmin Babası Thomas Cook Kimdir: https://www.bagimsizhavacilar.com/modernturizmin-babasi-thomas-cook-kimdir/> (Erişim Tarih. 01.11.2020).

Palace on Wheels: Exploring Rajasthan In Royal Style Aboard India's Top Luxury Train: https://www.youtube.com/watch?v=itT8cPGOoAM> (Erişim Tarihi: 10.02.202).

Rocky Mountaineer Train Journey - All Aboard from Vancouver to Banff: https://www.youtube.com/watch?v=VQTDIAL3S2A\&t=314s> (Erişim Tarihi: 10.02.2021).

$\mathrm{Su}, \mathrm{M}, \mathrm{M}$. and Wall, G. (2009). The Qinghai-Tibet Railway and Tibetan Tourism: Travelers ‘Perspectives. Tourism Management, 30: 650-657.

Sünnetçioğlu, A., Sünnetçioğlu, S. ve Mercan, Ş, O., Özkök, F. (2020). Seyahat Etme Niyetinde Sosyal Medyanın Rolü: Instagram'daki Kars Doğu Ekspresine İlişkin Yorumların Değerlendirilmesi. The Third International Congress on Future of Tourism: Innovation, Entrepreneurship and Sustainability. (Erişim Tarihi: 10.02.2021).

Temizgüney, F. (2015). Demiryolu Ulaşımının Erzurum'a Katkıları, Atatürk Üniversitesi Türkiyat Araştırmaları Enstitüsü Dergisi, 53: 255-272.

Thirumaran, K. and Raghav, M (2017). Luxury Tourism, Developing Destinations: Research Review and Trajectories. Asian Journal of Tourism Research, 2: 137-158.

Three Days on Board The Ghan Train: https://www.australia.com/en/trips-anditineraries/adelaide-and-surrounds/3-days-on-board-the-ghan-train.html> (Erişim Tarihi 07.02.2021)

Turistik Doğu Ekspresi - TCDD Taşımacılık AŞ Genel Müdürlüğü (tcddtasimacilik.gov.tr). Erişim Tarihi: 09.02.2019.

Yıldırım, A. ve Şimşek, H. (2008). Sosyal Bilimlerde Nitel Araştırma Yöntemleri (6. Baskı), Seçkin Yayıncilık, Ankara. 